\title{
EL DEBAT DE LES HUMANITATS: LLUMS I OMBRES
}

\author{
Antoni Gavaldà i Antoni Santisteban. Àrea de Didàctica de les Ciències Socials
}

El 16 de desembre de 1997 es retirava del Congrés dels Diputats el projecte de Real Decreto pel qual es pretenia establir uns ensenyaments mínims, corresponents a les àrees de Ciències Socials, Geografia i Història, i les de Llengua Castellana i Literatura a l'ESO. L'esborrany que des del govern conservador s'havia intentat defensar a tort $\mathrm{i}$ a dret ha originat una gran polèmica al món de la política i entre la comunitat educativa. Des de l'àrea de la Didàctica de les Ciències Socials pretenem analitzar què ha succeït, amb la intenció de valorar el debat, les causes i les conseqüències que ha comportat, el grau d'utilitat i de qualitat que ha generat, la reacció del professorat i de la societat en general, així com els elements ideològics i curriculars que han dominat o que, des d'una perspectiva crítica, haurien d'haver predominat. La nostra opinió, explicitada tot seguit, té com a idees bàsiques sintetitzades les següents (1):

a) El debat de les humanitats ha volgut substituir un altre debat més lògic, més científic i més necessari, que s'havia produït abans i durant la implantació de la Reforma per una part important del professorat, encara que no per la majoria. Així, en part, s'ha volgut recollir el descontentament del professorat oposat a una renovació, i que, cal dir-ho clar, va intervenir poquíssim en la planificació de la Reforma, per sentir-se poc interessat per les qüestions curriculars i didàctiques o per sentir-se marginat per la mateixa Administració. Conseqüentment, opinem que el fons del debat no és realment el debat sobre les humanitats, és el debat sobre la Reforma, en un intent d'atacar els seus principis a través d'un tema sobre el qual resulta fàcil fer demagògia, sobretot quan intervenen els mitjans de comunicació de masses, mediatitzats pel poder polític. Cal convenir que la majoria del professorat reconeix la necessitat d'algun tipus de debat sobre aquesta i sobre altres qüestions educatives, però no està d'acord amb els plantejaments dirigistes del currículum des de qualsevol administració que els pretengui imposar.

b) La clau de la millora de la renovació o de l'avenç de l'ensenyament i l'aprenentatge de les Ciències Socials no es troba en el debat sobre qüestions com les escales territorials, ni sobre l'ensenyament d'uns determinats fets o sistemes conceptuals des d'una o altra perspectiva. L'important, reiterem, no és si s'ensenya més o menys Història de Catalunya o d'Espanya, sinó quina història de Catalunya i d'Espanya s'hauria d'ensenyar i com fer-ho per formar ciutadans compromesos i participatius. Tot i reconeixent la importància d'aquests aspectes, la clau per avançar estaria a saber quines han de ser les finalitats de l'ensenyament de les Ciències Socials, saber per a què serveixen, quina és la seva funcionalitat i què poden aportar a la vida i a la maduració de les persones. Aquest és el veritable debat pendent, que hauria d'ajudar a canviar la concepció de l'ensenyament de les Ciències Socials, que canviaria el currículum i que canviaria la intervenció didàctica del professorat.

c) Amb el debat hem après una mica més sobre ideologia i currículum, sobre continguts i neutralitat, sobre coneixements $\mathrm{i}$ valors, però també sobre pedagogies invisibles o currículum ocult. La ideologia conservadora del govern ha topat amb l'autonomia del professorat i de països com Catalunya i amb governs d'altres parts d'Espanya. La visió centralista, uniforme i fins i tot totalitària ha aparegut en el fons i en la forma, en el continent $i$ en el contingut, amb ímpetu i males arts. Les posicions s'han radicalitzat amb un debat innecessari, i és possible que avui en dia aquest hagi generat més nacionalisme espanyol, i al mateix temps, major reafirmació de nacionalismes perifèrics.

\section{Precedents legals d'un debat}

El Reial Decret, aprovat el 1991 i avui encara vigent, en el moment de la seva redacció va ser objecte d'un intens debat que va durar uns dos anys entre el govern central i els de les diferents comunitats autònomes. Es va discutir objectiu per objectiu, contingut per contingut, respectant de forma global els continguts mínims establerts per la LOGSE, xifrats en un $65 \%$ i un $45 \%$, en funció de si eren definits per a comunitats amb una única llengua a aprendre o bé amb dues. En certa manera el decret de 1991 recollia l'opció per un currículum obert que permetés a les comunitats autònomes concretar els seus propis dissenys.

El projecte de decret d'humanitats de 1997 ratllava la frontera, apropant-lo a un currículum tancat. En història, per exemplificar-ho globalment, pretenia tornar a una visió més política que social, aspecte ja del tot superat. D'altra banda, el decret vigent de 1991 comença 


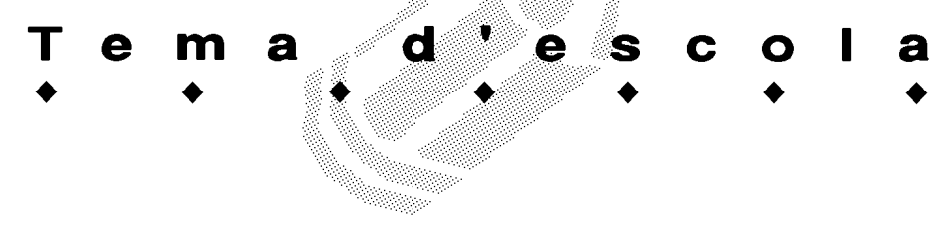

amb dos temes procedimentals importants, com són els mètodes històrics i el temps històric. Per contra, el projecte 1997 ignorava aquests temes i es convertia en una relació de continguts factuals per ordre cronològic, excessius, i al mateix temps -i pel flagrant oblit de continguts procedimentals i de valors socialsinsuficients.

El projecte 1997 presentava altres peculiaritats. Hi surava una intencionalitat manifesta en el problema del tractament del concepte de nació i de país, de nacionalisme i diversitat dins de l'Estat, que delatava una concepció confusa del mateix estudi de la societat. Es qualificava Espanya d'àmbit nacional, de país i d'Estat, se citaven les minories nacionals en referència al respecte i a la solidaritat amb els immigrants i no es feia una afirmació de les nacionalitats dins de l'Estat espanyol (2). Una llei educativa, opinem, no es pot presentar amb un intent de definir conceptes amb tanta càrrega ideològica, i per tant, conflictiva, entrant fins i tot en contradicció amb d'altres lleis de superior rang. S'ha de presentar la problemàtica, però no es pot pretendre l'adoctrinament per la via de la globalitat i la uniformitat.

Les promeses del Partit Popular, fetes abans de les darreres eleccions, sobre la necessitat de frenar i donar una direcció diferent a la Reforma educativa del 1991, o respecte al plantejament educatiu de determinats valors, es reflecteixen en aquest projecte de decret. Altres concepcions de càrrega ideològica semblant n'han estat la mostra en la importància i professió de fe del «españolismo» o en l'uniformisme centralista, les quals, per ara s'han vist seriosament i clarament rebutjades. La torna segurament no es farà esperar.

\section{Per què tanta importància a les humanitats?}

Molts governs conservadors s'han caracteritzat per produir un retrocés a l'ensenyament de les humanitats. És veritat. Per altra banda, aquests mateixos governs s'han caracteritzat per pretendre un renaixement d'un determinat tipus d'ensenyament de la Geograifa i de la Història, basada en una aclamació del patriotisme, de la simbologia nacionalista i en els elements més superficials de la cultura, com poden ser-ho la recordança de dates i de gestes d'herois elevats a mite.

L'aprenentatge de les Ciències Socials és important, creiem, per altres qüestions de més calat. Ho és perquè desenvolupa una part essencial de les nostres capacitats, ja que ajuda a madurar a les persones i les fa més hàbils per resoldre determinats problemes de vida quotidiana i científics. L'aprenentatge creatiu que es conforma amb l'estudi de les Ciències Socials és útil també per a la investigació tecnològica o de qualsevol altre tipus científic, de tal manera que es pot afirmar que les humanitats en el seu conjunt han de ser ensenyades al conjunt de la societat (Eisner, 1987).

La Història ens permet mantenir la cultura del temps $i$ en el temps, donar sentit a les tradicions i saber que
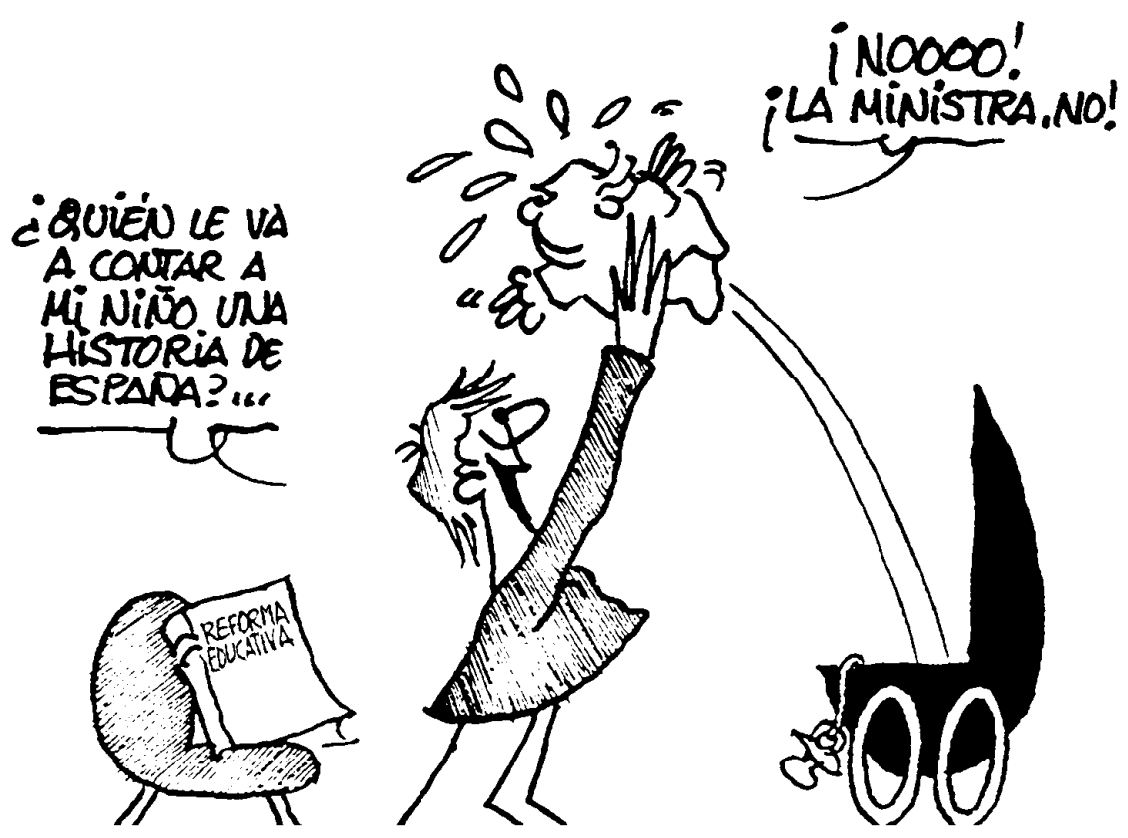

Nando. «El Periódico», 18-12-97 


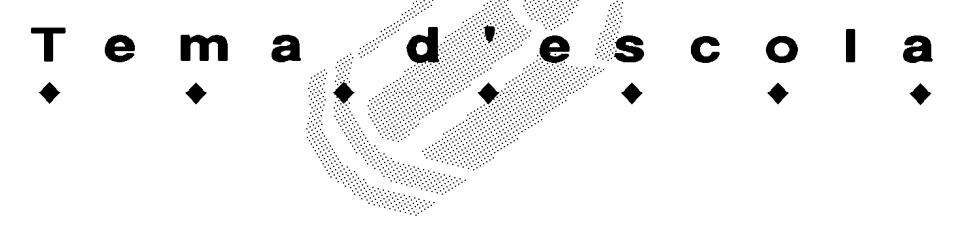

nosaltres mateixos formem part d'un espai que canvia i també podem decidir canviar. La perspectiva social de la Història dóna sentit tant al passat com al futur; el temps anterior que reconstruïm s'equipara al temps posterior que imaginem, que planegem o que construïm. La democràcia té com a base el coneixement històric, la intervenció social i la construció del futur. La Història és una excel-lent eina de coneixement i de crítica $i$ "es necessari que ens posem conjuntament a reparar-la i a posar-la a punt per poder fer front a un futur incert $\mathrm{i}$ difícil" (Fontana, 1992).

Malgrat tot, l'aprenentatge de la Història per si mateix no significa pas que s'afavoreixin capacitats com les indicades. Fins i tot pot provocar un efecte contrari, quan es converteix en un coneixement d'acumulació de dades i de dates. Qualsevol llista de coneixements ha de partir de la intencionalitat, del model didàctic que els sustenta, ja que si no és així es converteix en un material buit i inútil o al servei d'un aprenentatge memorístic, poc significatiu, irrellevant.

La Reforma educativa que en aquests moments es comença a aplicar ha de buscar complir objectius com els exposats, i incloure els elements necessaris de debat per perfilar possibles desajustos. L'esforç ha de tendir a primar els aspectes psicopedagògics més indiscutibles $\mathrm{i}$ a racionalitzar la selecció de continguts de la matèria. Però a més, es necessita de l'esforç del professorat per fer possible una millora del procés d'ensenyament-aprenentatge global.

Projectes com el d'humanitats del 1997 no estan en consonància amb les finalitats 0 les necessitats que demanda la societat i que hem apuntat de refiló. En primera instància l'aprenentatge de les Ciències Socials no serviria per formar un pensament creatiu, ni crític, ni per resoldre problemes. Per altra banda, la Història que s'hagués ensenyat no permetria ni la més mínima possibilitat de pensar sobre quin futur construir, ja que el passat seria aclaparador, dominant. Tanmateix, el professorat no se'l pot convèncer de cap de les maneres quan se li nega la possibilitat de realitzar adaptacions a la realitat històrico-social on viu. Que ho faci o no, malauradament, és un altre problema.

\section{És necessari el debat sobre les humanitats?}

Som de l'opinió que sempre és necessari el debat. Des de la perspectiva de la Didàctica de les Ciències Socials, una àrea de coneixement en contínua renovació i canvi, el debat ens és imprescindible. Tot amb tot, opinem que sembla una mica fora de context voler realitzar aquest gran debat educatiu sobre el tema, quan ja existeix una profunda reflexió que per altra part s'ha traduït en un fèrtil augment de publicacions, fruit d'una investigació seriosa i constant.

Sembla que el debat de les humanitats s'ha plantejat al marge de qui l'estava duent a terme. D'aquesta manera podem entendre que del grup d'experts que van confegir el projecte 1997, presidits pel catedràtic d'Història Contemporània de la Universitat de Valladolid, Celso Almuiña, acompanyat d'un bon grup de professors d'aquesta mateixa Universitat i d'altres professors entre els quals cal incloure-hi el català Pere Molas, catedràtic de la Universitat de Barcelona, no hi hagués ni un sol representant de l'àrea de Didàctica de les Ciències Socials, experts potencials del tema. L'abús de planteig des del ministeri era provocador, d'entrada.

Les reivindicacions dels que propugnen el debat actual sobre les humanitats acostumen a centrar-les a reclamar més terreny, més temps, més classes, més temari. Més camp per a la Filosofia, més oportunitats per al Llatí o el Grec, més importància per a la Història, més espai per a la Literatura. Alhora, una de les qüestions que s'accepten en general des de qualsevol camp de coneixement educatiu és que han d'estudiar-se conceptes en profunditat, temaris encaixats de forma global metodològicament ben dissenyats, temes d'una certa globalitat on es tinguin en compte enfocaments des de procediments diversos $\mathrm{i}$ es reflexioni sobre els valors que transmeten. Aquesta nova realitat comporta la necessitat de pensar per actuar; conseqüentment cal una complexa selecció de continguts, i això implica que determinats continguts estan millor situats en el punt de partida que d'altres. L'important no és tant només veure què ha d'aportar una determinada àrea de coneixement sinó, i sobretot, què han d'aportar les diferents àrees en el desenvolupament personal de qui s'està educant de forma obligatòria.

Un dels factors que afavoreixen regularment el debat sobre les humanitats és el que surt a la palestra respecte a la denúncia del retrocés de determinats coneixements entre la joventut, el desconeixement de determinats personatges històrics o polítics, les dificultats d'escriptura o la falta de certs valors socials. Afirmar que temps passats van ser millors reflecteix un tòpic que es repeteix des de sempre i que, en general, no presenta bases reals d'apreciació. La joventut d'avui en dia està més preparada (3).

\section{Quin és el debat actual sobre la Reforma educativa en el debat de les humanitats?}

El projecte en qüestió s'ha considerat per una part del professorat com una actitud de contrareforma i, òbviament, cal considerar-ho. No sembla adequat 


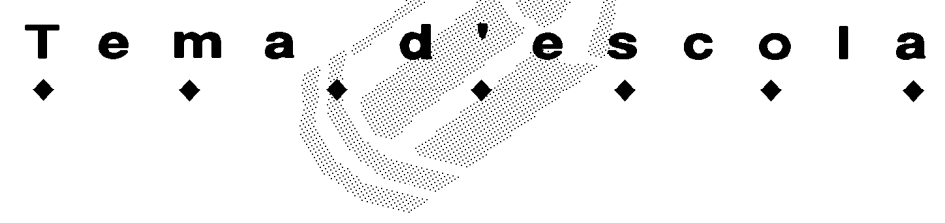

plantejar-se una modificació de la Reforma educativa en el moment inicial de la seva aplicació. S'ha de tenir ben present que el debat sobre la Reforma s'està fent des de fa deu anys, tot i que, cal acceptar-ho, en força ocasions no ha estat un debat profund i formatiu.

D'una banda, s'han d'assenyalar quins són els aspectes de millora del sistema respecte a la situació anterior, així com la conveniència del canvi i de la renovació professional. De l'altra, s'han de remarcar el que són problemàtiques generades per l'organització del nou sistema, que podem exemplificar, sense entrar-hi aquí, en l'organització voluntarista, en la deficient actuació de les administracions, en l'historial ambigu d'alguns centres, en la reordenació professional del professorat, etc.

De fet, cada estament hauria de reflexionar sobre el paper que ha jugat i la seva responsabilitat en el camí de millora i d'innovació educativa, començant per l'Administració, els mitjans de comunicació i el professorat escèptic i oposat al canvi, en defensa dels seus privilegis. Hem d'aclarir ja que la Reforma va ser impulsada pels sectors més progressistes de la societat. La vàlua dels Moviments de Renovació Pedagògica a nivell experimental i les aportacions de la psicopedagogia a nivell teòric en van ser els avaladors. Els dissenys curriculars, fins i tot amb les devaluacions posteriors, van significar una millora indiscutible.

La Reforma continua essent necessària i vàlida. En tot cas, les deficiències del nou sistema es deuen més a una falta de planificació administrativa, basada en una inadequada formació del professorat i en l'adequació dels centres públics que no per la validesa de la renovació que suposa el nou sistema. Opinem que és necessari defensar el nou model educatiu i apostar de manera decidida per un ensenyament de qualitat. El professorat ha d'exigir i ha de ser capaç, alhora, de decidir què, quan i com ensenyar i què, quan i com saber valorar aquest ensenyament. El professorat no ha d'estar dirigit per l'Administració amb un programa uniformat, sinó en collaboració, ni ho ha d'estar per interessos comercials, ni religiosos o de les editorials dels llibres de text. Ningú pensaria en un metge implicat -i aplicat- a qui l'hospital li digués com hauria d'observar els pacients i quin tractament o quins medicaments hauria de receptar. El professorat, a més, ha de ser un agent crític i compromès amb la societat.

El millor del debat de la Reforma educativa ha estat la circusmtància de voler participar en el mateix debat. Hem de veure, alhora, que la renovació i el canvi havien correspost fins ara a una minoria, sense l'exclusió que s'hi incorporés la necessària majoria. Per altra banda, també és important entendre que el debat educatiu no s'acaba amb la Reforma educativa. El debat educatiu és, abans que res, una actitud per avançar en el coneixement de l'ensenyament i de l'aprenentatge, en el nostre cas, de les Ciències Socials. Per això els debats no els hem d'estroncar.

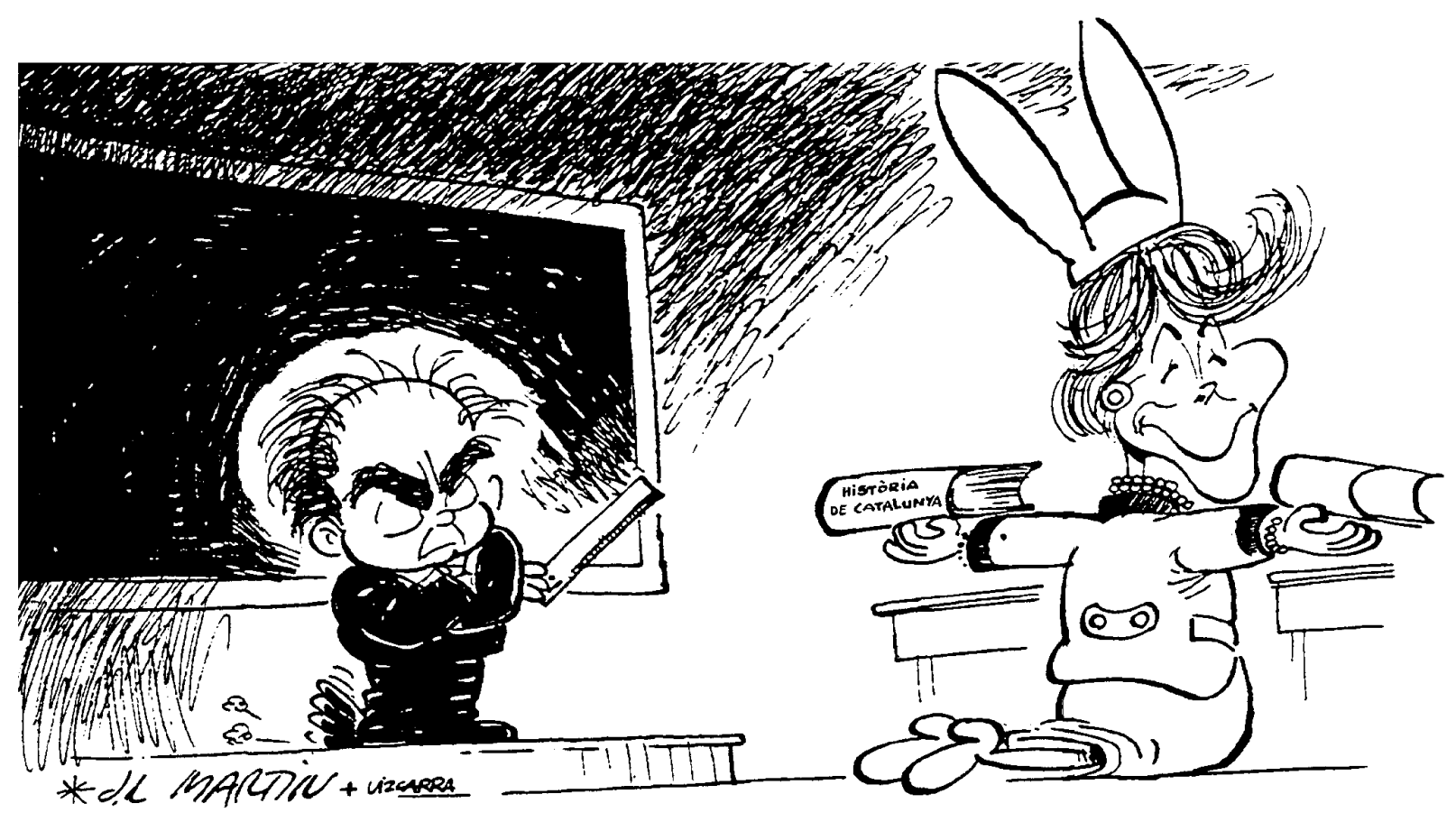

José Luis Martín. «El Periódico», 26-10-97 


\section{$T \circ m a .4: 0 \% 0 \% 19$}

\section{Continuïtats, ideologia i currículum}

És coneguda la idea de Pierre Vilar al reflexionar sobre la Història, que igual que existeix una continuïtat en el temps també existeix una continuïtat en l'espai. Sovint justifiquem debats sobre escales territorials 0 sobre la necessària selecció de continguts de Ciències Socials sense una lògica didàctica, sinó des d'una intenció político-ideològica que pot arribar a deformar el veritable debat dels aprenentatges, fins i tot des d'un enfocament crític (Rozada, 1997 i Apple, 1986).

El ensenyants de Ciències Socials hem de saber de la història d'Espanya que hem fet plegats i de la que hem estat en contradicció. Prosseguint amb aquest plantejament, s'ha de valorar quina història ens és comuna i quina no ho és tant. I des de la resta de l'Estat s'han d'analitzar, tanmateix, i valorar i interpretar el tipus de relacions que han existit entre les diferents regions i nacionalitats i el poder central. Les relacions d'opressió, de conflicte, d'economia dirigida, d'imposició, de menyspreu, de silencis, de pors, de venjances, de finalitats... s'han de saber distingir en una part de la història que, indiscutiblement, ens és comuna. El que no pot negar-se és que aquestes relacions han existit, així com l'existència d'uns objectius i concepcions diferents des de la vessant social i econòmica $o$, simplement, no han existit aquests objectius. Uniformitzar programes no és pas una garantia per saber el que és propi en connexió amb el del veí, sinó, potser, només valorar el que és propi com a únic i ignorar les diferències de personalitat (4). La història, tot i ser una ciència que analitza el conflicte, ha de saber analitzar també la concòrdia, la unió i la llibertat.

El debat de les humanitats ha estat també el debat sobre la ideologia del currículum. Giroux (1990) al referir-se a la selecció de continguts diu que "la forma en què se selecciona, s'ordena i se seqüencia la informació per construir un quadre de la realitat contemporània 0 històrica és alguna cosa més que una operació cognitiva; és també un procés íntimament lligat a les crences i als valors que guien la pròpia vida".

De fet, quan les intencions educatives són analitzades a través de la selecció de continguts, descobrim també els coneixements didàctics que s'han posat en joc durant la seva selecció (Popkewitz, 1985). La simple suma de continguts factuals o conceptuals és l'exemple més clar d'ignorància didàctica i demostra, tanmateix, que el que es perseguia era plasmar determinats fets des d'una posició política. A Catalunya no és pas el primer exemple que tenim d'imposició de coneixements factuals, incorporats sense criteris didàctics. El 1988, poc abans de la celebració del mil.lenari de Catalunya, el govern de la Generalitat es va alarmar quan, malgrat el canvi polític que s'havia produït des de 1981, no s'havien articulat unes directrius sobre quina Història de Catalunya s'havia d'ensenyar. Quan es decidí a presentar la proposta es va descobrir que uns experts -que renegaven dels coneixements psicopedagògics i didàctics- s'havien limitat a afegir al programa oficial les concrecions dels temes per a Catalunya, de tal manera que el programa quasi es multiplicava per dos. En aquella ocasió tampoc s'adonaren que existia un debat prereforma entre el professorat, que havia aprofundit amb esforç per resoldre aquests temes $\mathrm{i}$ no se'ls havia escoltat. Les queixes del professorat a l'acte de presentació dels nous programes, aprofitant un Simposi de Ciències Socials, amb sis-cents professionals, van ser ostentoses, sonores i tallants.

\section{El parer dels alumnes d'educació inicial}

La talaia que des del propi treball podem experimentar sobre aquest i d'altres temes en la investigacióacció és prou important, per la circumstància d'ensenyar a futurs professors que impartiran Ciències Socials a Infantil i Primària, a l'espera de col-laborar amb ensenyants d' Educació Secundària Obligatòria (5). Entre aquests alumnes de Primària hem fet una prova de la capacitat de discernir, per grups, condició básica per poder opinar. Volem que, tot $i$ tenir un temari consensuat a inici de curs, tinguin l'opció d'opinar sobre aspectes de Ciències Socials que els afecten, motiu pel qual tenim un programa obert que ens permet reflexionar sobre assumptes educatius, de caire social. Un dels temes era treballar els mapes conceptuals, amb els quals volem mostrar com la síntesi d'un determinat tema pot presentar particularitats en funció de les idees clau amb les quals s'articula el referit tema.

El mapa conceptual que presentem, fet per alumnes, mostra com es va viure el problema de les humanitats, articulat al voltant de l'eix de trencament de la Reforma (6). Els alumnes que feren el mapa es plantejaren tres mòduls de treball: la justificació, en positiu i en negatiu; els elements didàctics en aspectes contrareformistes; i la vessant de la ideologia des de l'òptica tradicional. Tot i que aquí no és el moment de fer una anàlisi del mapa, veiem que el que primaren van ser els elements didàctics, suposadament per dues qüestions: perquè la visió des de la Psicologia de l'Educació la tenen més fixada del que ens creiem al posar unes aspes de trencament de conceptes que no concorden amb el que han vist i practicat fins ara; i perquè el disseny des de la Didàctica de les Ciències Socials aplicat a l'ensenyament de l'àrea reforça les idees que el currículum ha d'integrar reflexivament, des del conflicte al consens, des de la permisivitat a l'exigència, des 


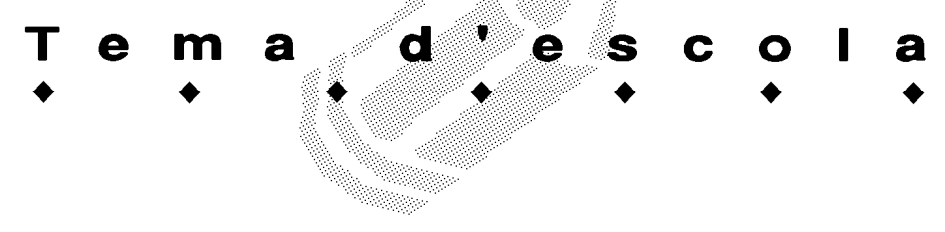

de la història d'entorn a la història del país; sempre, però, amb problemàtiques clares i que puguin resoldre's amb més d'una via.

\section{El parer dels professionals de l'ESO}

La circumstància que es parlés a bastament del decret d'humanitats i que la premsa se'n fes ressò a través de molts escrits i opinions, i es resolgués, inicialment per la via parlamentària, va fer que preguntéssim als professors en exercici d'ESO sobre qüestions del currículum de Ciències Socials que estaven aplicant. Sobre una enquesta-qüestionari prèviament elaborada es demanava que marquessin amb una creu la possible resposta de les que es donaven i es deixava espai per si volien justificar la resposta. Es reberen 12 respostes de companyes i companys en exercici de diversos IES de la demarcació.

La primera qüestió era saber la valoració que en feien del currículum de Ciències Socials a l'ESO, d'1 a 5, de menys a més. Les respostes estan totes al terme mig. Majoritàriament, o sigui 6 IES marcaren la casella del 3 , significació que cal entendre com a normal; 3 posaren un 2 i 3 posaren un 4. Respecte a les respostes, les podem englobar en quatre eixos per ordre de més respostes a menys: 4 IES digueren que el programa era massa dens per a poder-lo desenvolupar en 35 hores; 1 posava que era desmesurat, repetitiu i amb carències greus; 2 manifestaren que la forma de treballar en continguts procedimentals els era interessant; 1 argumentava que es feia massa incidència en història contemporània, qüestió que no creia que hagués de ser així; 1 ficava el dit a la nafra indicant que hi havia conceptes abstractes que eren difícils per a alumnes de primer cicle.

La segona qüestió es referia a què pensaven de la quantitat de continguts d'Història als programes actuals de l'ESO, amb 4 possibles respostes que alguns marcaren amb més d'una creu, les quals han donat el següent resultat: 5 IES opinaren que són força adequats; 5 que són massa, 3 que són inadequats, i 1 que són pocs.

Les respostes justificatives aporten claredat a la pregunta. Un dels instituts que van optar per indicar que eren massa repetia que es necessitarien més hores per ensenyar bé tots els continguts del currículum; un dels que optaren per posar adequats va perfilar la resposta dient que els permetia treballar altres temes aprofitant l'espontaneïtat dels alumnes, i un altre va indicar que els continguts procedimentals l'absorbien; els dos que assenyalaren que eren inadequats ho argumentaren indicant que els temes eren tractats desigualment, que es feia poc aprofundiment i que es perdia l'evolució històrica.

La tercera qüestió es referia a la importància del llibre de text en la programació, amb 4 possibles respostes: 4 digueren que hi donaven molta importància, amb apreciacions com que cal poca distracció per avançar, perquè si no, els alumnes anirien perduts; que el llibre de text disposava de bons continguts procedimentals i que era pràctic sobretot per als crèdits comuns; 7 apostaren per força importància concretantho que si convenia s'adaptava, però que era bàsic treballar amb llibre de text o que era una guia necessària per a alumnes amb nivells massa elementals,

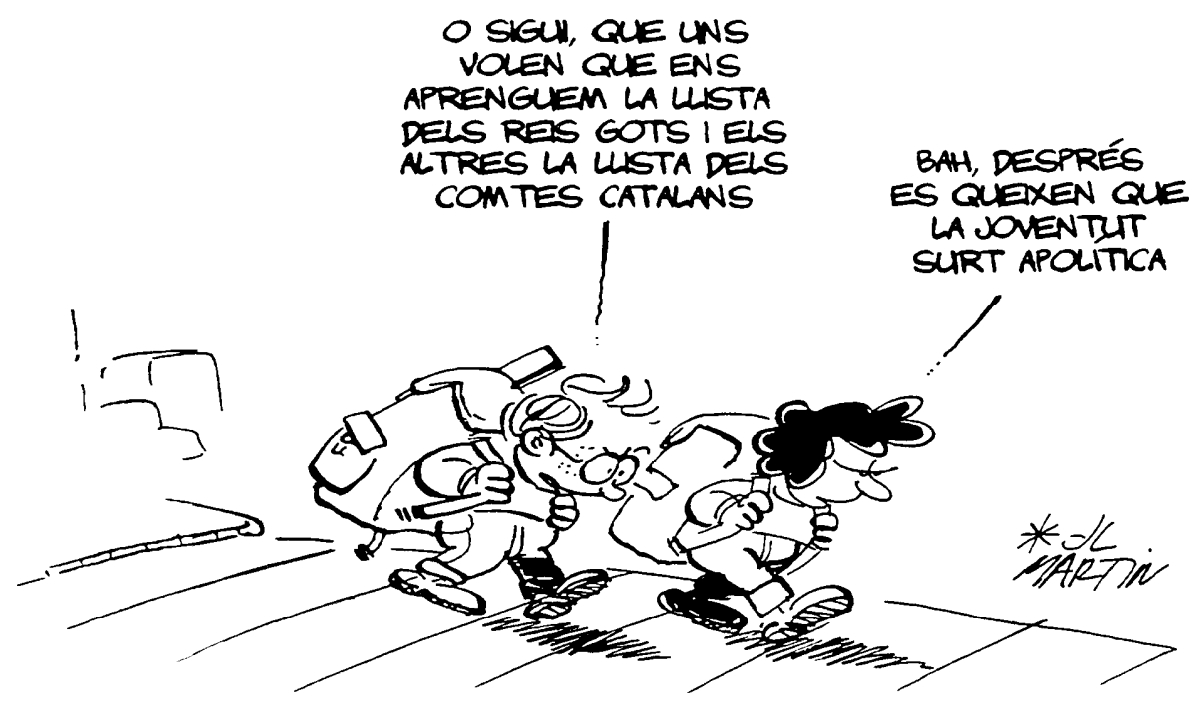

José Luis Martín. «El Periódico», 2-11-97 


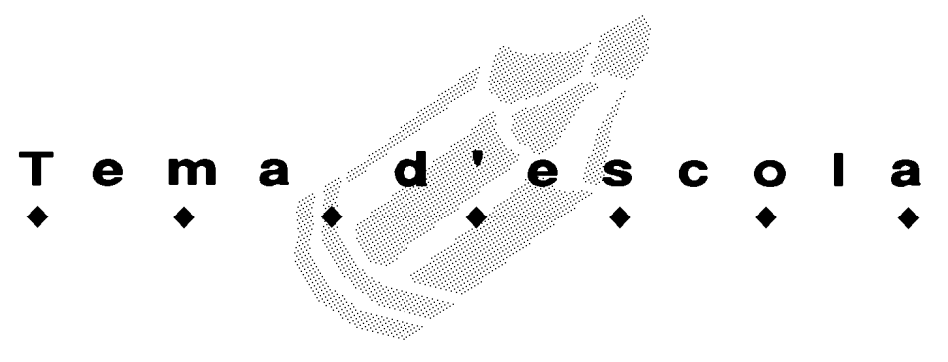

circumstància que impossibilitava que prenguessin apunts; i 1 se significa per la poca incid§ència del llibre, explicant que feia ús de dossiers elaborats per professors.

La quarta i darrera qüestió es perfilà buscant saber el tractament de la història de Catalunya i d'Espanya al programa, amb sis possibles opcions, de les quals només se n'utilitzaren quatre. Les respostes, de més a menys, van ser: 6 IES digueren que l'opció era "altres", argumentant que el tractament que donaven era d'història general o universal, exemplificant els models a Catalunya o Espanya, tot i que sovint faltava temps per fer-ho a totes dues realitats o significant també en una altra resposta que l'ordre era història a nivell universal per sobre de la història d'Espanya, tractada a nivell 'anecdòtic', i molt menys d'Història de Catalunya, a la qual ja quasi no s'hi arribava; 3 marcaren la creu que la història de Catalunya era l'eix principal del programa, posant en un cas que particularment no estava d'acord a transmetre "valors espanyols", però sí a conèixer els fets de la història d'Espanya; 3 posaren que la història de Catalunya era l'eix principal del programa, però es feien contínues referències a la història d'Espanya; i 1 que la història d'Espanya era l'eix bàsic del programa, però es feien contínues referències a la història de Catalunya.

\section{A manera d'epíleg, per ara}

Amb el precedent $i$ amb el que marca la ciència no és d'estranyar que el president de l'Associació Universitària de Didàctica de les Ciències Socials, a nivell de tot l'Estat, demanés debat científic a la ministra per la possible reformulació dels continguts d'una àrea que està en el segon curs de funcionament dels quatre que ha de tenir. I, sobretot diàleg.

La síntesi, en dues apreciacions que ens és grat d'exposar, sense espai per ampliar, passa perquè la història ha tingut una funcionalitat política, on tots els estats han volgut preservar els seus continguts, sense oblidar uns mites i unes dates que sovint només s'aguanten per una política d'exaltació nacional o nacionalista pròpia d'una història encarcarada, que potser hauria hagut d'evolucionar fa força d'anys, conforme la ciència històrica ha anat avançant, i que ara rebrota amb força per unes polítiques mal resoltes i encaixades.

La segona idea-eix que volem assenyalar és que en el futur de la història cal retrobar-nos en relació amb la història viscuda per les persones i no amb la història soferta, amb la història de les evolucions i les transformacions i no amb la història en compartiments estancs, amb la història explicativa i no la història només narrativa, descriptiva o dogmàtica. I feta, i entesa, i en construcció, entre tots.

\section{Notes}

(1) Aquest treball s'ha publicat parcialment a Boletín Informativo. Asociación Universitaria del Profesorado de Didáctica de las Ciencias Sociales. ED. UAB. Bellaterra, pàgs. 10 a 15 , amb el títol "Qué debate se ha producido sobre la enseñaza y el aprendizaje de las Ciencias Sociales?"

(2) Citacions que apareixen a l'apartat "Objetivos comunes a Historia y Geografía", puntos sèptimo y décimo, página 7, i a l'apartat de "Criterios de Evaluación. Historia. i) Prehistoria y Edat Antigua, punto sexto, página 14". Exemplar fotocopiat, cedit per la Inspecció de Catalunya. Delegació de Tarragona.

(3) El projecte d'humanitats utilitzà un treball de Ramon Canals, de la Universitat de Girona, per afirmar el retrocés educatiu. El mateix Canals denuncià aquesta utilització $i$ va afirmar que el que es produeix és un aprenentatge diferent, més procedimental i més funcional, en consonància amb les noves formes de vida, en què els mitjans de comunicació i les possibilitats d'accés a la informació s'han multiplicat. Entrevista publicada a E/ Periódico de Catalunya del 28 d'octubre de 1997.

(4) En certa ocasió la ministra Esperanza Aguirre negà que poguessin existir relacions de cap tipus entre Espanya i Catalunya, perquè les dues comunitats eren el mateix.

(5) És una via que quan la nostra Universitat es replantegi l'obsolet CAP caldrà intervenir-hi. Altres universitats ja han entrat en la necessària revisió.

(6) El realitzaren els alumnes de tercer de Primària $T$. Agustí, E. Cabré, T. Cousillas, I. Garcia, J.L. Linares, B. Roselló i T. Valentín.

\section{Referències bibliogràfiques}

APPLE, M.W. Ideología y currículo. Editorial Akal. Madrid. 1986.

EISNER, E.W. Proyectos cognitivos y currículum. Una base para decidir lo que hay que enseñar. Editorial Martínez Roca. Barcelona. 1987.

FONTANA, J. La història després de la fi de la història. Editorial Eumo. Vic. 1992. Pàg. 123.

GIROUX, H.A. Los profesores como intelectuales. Editorial Paidós. Barcelona. 1990.

POPKEWITZ, T.S. "Los valores latentes del currículum centrado en las disciplinas", en GIMENO SACRISTÁN, J. i PÉREZ GÓMEZ, A. (ed). La enseñanza, su teoría y su práctica. Editorial Akal. Madrid. 1985.

ROZADA, J. M. Formarse como profesor. Ciencias Sociales, Primaria y Secundaria Obligatoria (Guía de textos para un enfoque crítico). Editorial Akal. Madrid. 1997. 